\title{
Mortality Update for the Pantex Weapons Facility: Final Report
}


MORTALITY UPDATE FOR THE PANTEX WEAPONS FACILITY: FINAL REPORT HEALTH-RELATED ENERGY RESEARCH BRANCH

National Institute for Occupational Safety and Health 


\section{DISCLAIMER}

Mention of any company or product does not constitute endorsement by the National Institute for Occup ational Safety and Health (NIOSH). In addition, citations to Web sites do not constitute NIOSH endorsement of the sponsoring organizations or their programs or products. Furthermore, $\mathrm{NIOSH}$ is not responsible for the content of these Web sites.

\section{Ordering Information}

To receive documents or other information about occupational safety and health topics, contact $\mathrm{NIOSH}$ at

$$
\begin{gathered}
\text { NIOSH_Publications Dissemination } \\
\text { 4676 Columbia Parkway } \\
\text { Cincinnati, Ohio 45226-1998 } \\
\text { Telephone: 1-800-35-NIOSH (1-800-356-4675) }
\end{gathered}
$$$$
\text { Fax: 513-533-8573 }
$$

E-mail: pubstaft@cdc.gov

or visit the NIOSH Web site at www.cdc.gov/niosh 


\section{AUTHORS}

Silver, Sharon R, National Institute for Occup ational Safety and Health, Division of Surveillance, Hazard Evaluations, and Field Studies, Cincinnati, Ohio

Anderson-Mahoney, Pamela ${ }^{1}$, Health Research Association, Los Angeles, California

Burphy, Jenneh, Associated Schools of Public Health, Public Health Graduate Training Program, Atlanta, Georgia

Hiratzka, Shannon, Constella Group Inc., Durham, North Carolina

Schubauer-Berigan, Mary K, National Institute for Occupational Safety and Health, Division of Surveillance, Hazard Evaluations, and Field Studies, Cincinnati, Ohio

Waters, Kathy M, National Institute for Occupational Saf ety and Health, Division of Surveillance, Hazard Evaluations, and Field Studies, Cincinnati, Ohio

${ }^{1}$ Formerly with NIOSH 


\section{ABSTRACT}

In 1985, Acquavella, et al. [1985] reported the results of a cohort mortality study of white male workers ever employed at the Pantex Plant between 1951 and the end of study date, December 31, 1978. Compared to U.S. death rates, the mortality experience of these workers suggested a strong healthy worker effect overall, but non-significant elevations were observed for leukemia and brain cancer. For the current analy ses, the National Institute for Occupational Safety and Health (NIOSH) expanded the study population to include workers of both genders and all races ever employed between 1951 and 1978 and extended vital status follow-up through 1995. Summary Standardized Mortality Ratios (SMRs) were generated for these workers (the full NIOSH cohort).

Workers terminating or deceased by December 31, 1978, for whom complete employment records were available (the early-term subcohort), were included in SMR and Standardized Rate Ratio (SRR) duration of employment analy ses. The all-cause SMR for the early-term subcohort $(0.98,95 \%$ confidence interval $(\mathrm{CI})=0.92-1.05)$ was higher than that seen in the full NIOSH cohort (SMR=0.81, 95\% CI=0.76-0.86) and by Acquavella et al. [1985] (SMR=0.72, 95\% $\mathrm{CI}=0.64-0.81)$ and was close to that expected from U.S. population rates. Brain cancer was no longer elevated in the full NIOSH cohort (SMR=0.51, 95\% CI=0.17-1.19) in the updated analysis, although the confidence intervals span unity. The leukemia SMR was elevated (earlyterm subcohort SMR=1.47, 95\% CI = 0.73-2.63) but SRRs showed no evidence of a positive exp osure-resp onse relation with increasing duration of employ ment. Lung cancer SM Rs with 10and 15-year lags were just below expectation. Breast cancer was elevated only in workers with employment durations of 5 to 10 years. The SMR for prostate cancer was as exp ected, but this outcome showed a statistically significant p ositive exposure-response [slope: $1.36 \cdot 10^{-5}$ per person-y ear (PY) y year of employment (YOE), standard error: $4.31 \cdot 10^{-6}$ per PY·YOE], with a very high, though imprecise, point estimate $(\mathrm{SRR}=7.57,95 \% \mathrm{CI}=1.03-55.72)$ for workers employed at least 20 years with a 10-year lag imposed. Multiple myeloma also exhibited a statistically significant positive exposure-response. Due to the potential for positive bias in the early-term subcohort, caution should be exercised in generalizing the exposure-response results. These findings suggest the need for collection of full employment information about workers employed beyond 1978, as well as the estimation of occupational exposure for Pantex workers. 


\section{ABBREVIATIONS}

$\begin{array}{ll}\text { ATSDR } & \text { Agency for Toxic Substance and Disease Registry } \\ \text { CI } & \text { confidence interval } \\ \text { DOE } & \text { U.S. Department of Energy } \\ \text { ICD } & \text { international classification of disease } \\ \text { LTAS } & \text { Life Table Analysis System } \\ \text { mSv } & \text { millisievert } \\ \text { NDI } & \text { national death index } \\ \text { NIOSH } & \text { National Institute for Occupational Safety and Health } \\ \text { PC-LTAS } & \text { personal computer Life Table Analy sis System } \\ \text { PY } & \text { person-y ear } \\ \text { REM } & \text { Roentgen Equivalent Man } \\ \text { SE } & \text { standard error } \\ \text { SMR } & \text { standardized mortality ratio } \\ \text { SRR } & \text { standardized rate ratio } \\ \text { SSA } & \text { Social Security Administration } \\ \text { YOE } & \text { years of employment }\end{array}$




\section{INTRODUCTION}

The U.S. Department of Energy (DOE) Pantex Plant, located near Amarillo, Texas, origin ated as a conventional ammunitions loading facility but became involved with assembly and disassembly of nuclear weap ons in 1951. The facility's functions include assembling conventional high explosive and nuclear materials into new nuclear weap ons, maintaining and testing existing nuclear weap ons, disassembling these weap ons, and performing related research and development [DOE 1999]. Employees have been potentially exp osed to components of both nuclear weap ons and high explosives during these procedures.

As described by Acquavella et al. [1985], potential exp osures at the site include low-level external radiation from nuclear weapons components and from industrial radiographic equipment, as well as a number of solvents and other chemicals involved in high-explosives processing. Unfortunately, complete dosimetry information was readily available only for workers first hired after 1962 and industrial hy giene sampling was limited prior to 1973, limiting the feasibility of evaluating the health outcomes of specific on-site exposures.

In 1985, Acquavella reported the results of a cohort mortality study of workers at the Pantex Plant. The study compared total and cause-specific mortality for 3,564 white male workers ever employed between the start of plant operations in 1951 and the end of study date, December 31, 1978, with U.S. death rates. Females and nonwhite males were excluded because the relatively small numbers of such persons did not allow meaningful an aly ses. No exposure data were used except for identification of a subcohort of workers known to have cumulative recorded radiation exp osure of at least 1 rem (10 $\mathrm{mSv})$.

The small number of white male deaths (269) and relatively short length of follow-up of the workforce (average $=14.6$ years) limited the power of the study to detect statistically significant excesses or deficits in mortality rates, compared to expected rates. Overall mortality was below expectation, with a Standardized Mortality Ratio (SMR) of 0.72 (95\% confidence interval $[C I]=0.64-0.81$ ), a finding Acquavella and colleagues attributed to a strong healthy worker effect and short follow-up time. However, the authors did report non-statistically significant elevations for leukemia ( $\mathrm{SMR}=1.28,95 \% \mathrm{CI}=0.35-3.27,4$ deaths) and for brain cancer (SM R=1.36, 95\% $\mathrm{CI}=0.37-3.47,4$ deaths). The all-cause mortality rate was even lower among the 1-rem subcohort than in the general cohort. Lung cancer and cerebrovascular SMRs were higher in this subcohort, but these results were based on very small numbers (2 cases and 1 case, respectively) and CIs were quite wide.

Because the findings for leukemia and brain cancer warranted additional follow-up, the National Institute for Occupational Saf ety and Health (NIOSH) initiated a limited analy sis to up date the cohort's mortality experience and to examine mortality trends with increasing duration of employment. Resources to identify, collect, and code additional employment and exposure records were not available at the time the current study was conducted, so duration of employment was used as a nonspecific measure of cumulative workplace exposures. 


\section{NIOSH STUDY POPULATION}

The current study population includes all males and females, regardless of race, ever employed at the Pantex facility between the start of operations in 1951 and December 31, 1978. Vital status follow-up was extended through December 31, 1995. This full NIOSH cohort comprises 4,668 workers. Because complete work history information was not collected for workers who continued employ ment after December 31, 1978, analy ses involving duration of employ ment were limited to an early-term subcohort of 2,721 workers who had died or terminated employment before 1979. Analytic files included workers' sex and race, as well as dates of birth, hire, and termination (where available). Date and cause of death were included for workers known to be deceased. Vital status follow-up was conducted through December 31, 1995 using Social Security Administration (SSA) death tap es and the National Death Index (NDI). An attempt was made to obtain all death certificates for SSA- or NDI-confirmed deaths. A qualified nosologist coded all deaths according to the International Classification of Diseases (ICD) revision in effect at the time of each death. No cause of death was available for 44 people from the full NIOSH cohort, including 38 from the early-term subcohort. These deaths were retained in the all-cause SMR analyses and were included in the other unspecified cause of death category. Only underlying cause of death was considered in the analyses.

\section{NIOSH STUDY ANALYSIS}

The NIOSH personal computer Life Table Analysis Sy stem (PC-LTAS, version 1.0d) was used to generate expected numbers for all deaths, all can cer deaths, and cause-specific deaths for each race and sex within 5-year age and 5-year calendar time periods [NIOSH 2001]. Workers of unknown race (24.2\%) were assumed to be white. Hispanic workers were included in this category as well.

Expected and observed deaths were enumer ated for each of these age and calendar time periods from January 1, 1951 through December 31, 1995. Expected numbers of deaths were based on U.S. population death rates specific for the race, gender, and 5-year age and calendar time periods, applied to the number of person-years at risk of dying. Numbers of deaths observed for each cause were divided by the expected number of deaths to obtain cause-specific SMRs.

Outcomes of a priori interest based on a site summary rep ort of the Pantex Plant by the Agency for Toxic Substance and Disease Registry (ATSDR) describing community health concerns about a number of malignancies were as follows: lung, bone, prostate, brain, breast, thy roid, all cancers combined, leukemia, and malignant pleural mesothelioma [ATSDR 1996]. SMRs were calculated with no lag period for all LTAS causes of death. The statistical significance of each SMR was assessed assuming a Poisson distribution, with two-sided 95\% CIs.

Because SMRs are affected by the age structure of different exp osure categories within the study population, comparison of SMRs for exposure groups can be misleading. Standardized Rate Ratios (SRRs) allow for comparison among populations by weighting observed stratum-specific rates according to a common (internal) standard [Rothman 1986]. For the early-term subcohort, SMRs and SRRs were calculated for leukemia using 0-, 2-, and 5-y ear lag periods and for solid tumors using 10-, 15-, and 20-year lag periods. LTAS generates Taylor-series-based CIs for each 
SRR. For exp osure-resp onse analyses based on duration of employment, a linear trend is calculated in a regression of directly standardized rates. Statistical significance of each trend was determined using a two-tailed z-test with an alpha of 0.05 [Cassinelli et al. 1998].

\section{RESULTS}

\section{Demographics}

The demographics of the early- and late-term subcohorts and the full NIOSH cohort are shown in Table 1. The early- and late-term subcohorts were quite similar in sex and race, although the percentages of nonwhite males and females were somewhat higher, and the percentage of white females was slightly lower in the late-term subcohort. Mean age at hire and attained age (at death or end of study) were virtually identical. Both the full cohort and the subcohorts were still fairly young at end of follow-up, with $75 \%$ of workers aged 70 or younger (Table 2 ).

Vital status of the subcohorts at end of follow-up differed substantially (Table 3). While 1,032 members (22.1\%) of the full NIOSH cohort were deceased by the study end date, the early-term subcohort was $29.4 \%$ deceased, while only $11.9 \%$ of the late-term subcohort had died. A total of 175 workers were of unknown vital status, with 173 of these from the early-term subcohort. The latter were considered alive for all analy ses.

The other major difference between the early- and late-term subcohorts was the average duration of employment. Average duration of employment for the early-term subcohort was 4.4 years. Although duration from date of hire to termination date could not be determined for late-term workers due to lack of work history data (truncating employ ment for this subset of workers at the end of 1978), the last date of known employment for the group as a whole gave an average duration of 11 years. This figure underestimates the late-term workers' average duration of employment, but it is still more than double the average duration for the early-term subcohort. Finally, members of the late-term cohort were hired, on aver age, 6 y ears later than their earlyterm counterparts.

\section{Summary SMR Analyses, Full NIOSH Cohort and Early-Term Subcohort}

To evaluate the effects of restricting some an aly ses to workers who terminated employment as of 1978 (the early-term subcohort), we generated summary SMR figures (Table 4 and Appendix A) for both the early-term subcohort and for the full NIOSH cohort. The SMR for all-cause mortality still exhibited a healthy-worker effect in the full NIOSH cohort, at 0.81 (95\% CI=0.760.86), but was very close to exp ectation in the early-term subcohort at $0.98(95 \% \mathrm{CI}=0.92-1.05)$. Similarly, all-can cer mortality was further below expectation in the full NIOSH cohort $(\mathrm{SMR}=0.78,95 \% \mathrm{CI}=0.69-0.88)$ than in the early-term subcohort $(\mathrm{SMR}=0.86,95 \% \mathrm{CI}=0.74-$ 1.00). No deaths from bone or thyroid cancer, two outcomes of a priori interest, occurred in the subcohort. A number of other causes of death were below expectation, with no cases of tuberculosis or of malignant neoplasms of the tongue, peritoneum, cervix, uterus, eye, or connective tissue (Appendix A). Ischemic heart disease was also lower than expected, with CIs below 1.00 for both the full NIOSH cohort (SMR=0.70, 95\% CI=0.62-0.79) and the early-term subcohort (SMR=0.81, 95\% CI=0.70-0.94). 
Brain cancer was elevated in the original rep ort, but in the current analysis, the SMR for this cause of death was below expectation in the full NIOSH cohort (SMR=0.51, 95\% CI=0.17-1.19, 5 deaths) and the early-term subcohort ( $\mathrm{SMR}=0.67,95 \% \mathrm{CI}=0.18-1.71,4$ deaths). However, deaths from neoplasms of the eye, brain, and other parts of the nervous system, unspecified as to benign or malignant, were elevated, though with very few cases, in both the full NIOSH cohort $(\mathrm{SMR}=1.66,95 \% \mathrm{CI}=0.34-4.84,3$ deaths) and early-term subcohorts (SMR=1.76, 95\% CI= (0.21-6.34, 2 deaths). These poorly-classified deaths hinder definitive comparison of brain cancer deaths observed in these cohorts with the exp ectation from U.S. population rates.

For most causes of death, mortality rates in relation to the general U.S. population were lower, though confidence intervals are very wide, for the full NIOSH cohort than for the early-term subcohort. An exception was prostate cancer, which had very similar SMR results for the earlyterm subcohort (SMR=1.03, 95\% $\mathrm{CI}=0.55-1.76)$ and the full NIOSH cohort (SMR=1.05, 95\% $\mathrm{CI}=0.64-1.62$ ) with 10-y ear lags; results were similar with a 15-year lag imposed.

\section{SMR and SRR Duration of Employment Analyses, Early-Term Subcohort}

SMR duration runs and duration-based SRR analy ses were limited to the early-term subcohort (Table 5). This group exhibited a leukemia SMR of 1.47 (95\% CI=0.73-2.63) with no lag and an SMR of 1.50 (95\% CI=0.75-2.75) with a 2-year lag. However, in SRR an alyses, the exposureresponse trends were negative with both 0 - and 2-y ear lags, with the negative trend statistically significant with a 2-year lag (Figures 1 and 2). This negative trend is influenced by a deficit of cases among workers in the highest duration of employment category, $>=20$ y ears, with an SRR of $0.43(95 \% \mathrm{CI}=0.05-3.63)$ with a $2-y$ ear lag. For multiple myeloma, the SMR was elevated at 2.09 (95\% CI= 0.76-4.55, 6 deaths) with a 10-y ear lag and the exposure-responses were positive and statistically significant with 10- and 15-year lags (Figures 3 and 4). Prostate cancer had only a slightly elevated SMR, but the SRRs showed statistically significant positive exposure responses with 10- and 15-year lags, with very high, though imprecise, point estimates for workers employed for at least 20 years (Figures 5 and 6).

Several malign ancies which had SMR results below expectation (1.00) did show risk differences by duration of employ ment in the SRR analy ses (Table 4). Lung cancer was elevated in the two intermediate duration categories with a 10 -year lag and in the 5 to $<10$ year category with a 15year lag. However, the SRR was well below expectation for workers employ ed for at least 20 years, yielding a negative slope that was statistically significant with the 15-y ear lag (Figur es 7 and 8). The SMR for breast cancer in white females was also lower than expected at 0.85 (95\% $\mathrm{CI}=0.28-2.00,5$ deaths). This outcome was elevated in the category 5 to $<10$ years in both SMR and SRR analyses with no lag, but there were no deaths at any longer duration, so analyses with longer lags could not be performed. Similarly, while the SMR for pancreatic cancer was below expectation at 0.49 (95\% CI=0.16-1.15, 5 deaths), the unlagged SRRs were elevated in the 5 to $<10$ y ear and 10 to $<20$ y ear duration categories, with no deaths from this cause observed in workers employed for at least 20 y ears. The positive exp osure-resp onse was not statistically significant, and all cases shifted into duration categories below 10 years when lags of 10- or 15y ears were applied. 


\section{DISCUSSION, LIMITATIONS, AND RECOMMENDATIONS}

Attenuation of the healthy worker selection effect with additional follow-up has been noted before in occupational studies [Baillargeon et al. 1998]. Acquavella et al. [1985] observed a strong healthy worker effect among white male Pantex workers followed through 1978. Results for the full NIOSH cohort of all workers employed between 1951 and 1978, followed through 1995, show a weaker healthy worker effect.

A related phenomenon, the healthy worker survivor effect, has been observed in a number of occupational studies which found that workers who remain employed tend to be healthier than those who terminate [Siebert et al. 2001; Baillargeon and Wilkinson 1999]. The healthy worker survivor effect tends to attenuate exp osure-related risk estimates in a cohort that includes longterm workers. As the early-term cohort by definition excludes long-term workers who were healthy enough to continue employment beyond 1978, the healthy worker survivor effect is likely attenuated, leading to an upward bias of the SMR results, compared to mortality exp ectation for the full cohort. M embers of the early-term subcohort had shorter average employment durations than their late-term counterparts. Because of the 1978 employ ment cutoff, a worker in the early-term cohort first employed in 1960 could have worked at most 18 y ears, while a member of the late-term cohort first employ ed in 1960 would have worked any where between 18 and 35 years at Pantex. The shorter-term workers in the early-term cohort may have been more likely than their late-term counterparts to terminate employ ment due to ill health, have had poorer access to health care, or have had lifestyle factors detrimental to health, all suspected components of the healthy worker survivor effect [Kolstad and Olsen 1999]. Comparison of summary SMR results for the full NIOSH cohort and the early-term subcohort is consistent with this possibility, as SMRs for most outcomes are lower for the full cohort. Excluding healthy, long-term workers could also lead to a positive bias in the SRR results for the longer employ ment duration categories, and hence could be responsible in part for positive trends observed in the SRR analyses. These factors limit the generalizability of duration analyses bey ond the early-term subcohort. In the current analyses, the differences between the SMR and SRR results suggest that there are indeed differences in age structures of workers in the different duration categories and in the ages of cases at time of death; this suggestion was confirmed by examination of person-year distributions by age at accrual and final employment duration categories for leukemia and prostate cancer (Tables 6 and 7). These findings weigh in favor of preferential focus on the SRR results.

In addition to biases introduced by exclusion of workers with late termination dates, it is possible that truncation of early employment histories could affect the duration analyses. Employment dates for the NIOSH cohort came from the Acquavella files, where plant operation was considered to start in 1951. Non-nuclear work at Pantex began as early as 1942. It is possible that a subset of workers were first employed at Pantex before 1951 but that these early emp loy ment periods were discounted. However, the hire dates for the full cohort do not show a disproportionate number starting in 1951, so the number of workers affected and any resulting bias is probably limited. 
The elevated SMR for leukemia observed by Acquavella was again seen in this study, but the CIs include 1.0, and SRR analyses showed the risk decreasing with increasing duration of employment. It is important to note that these results are based on a total of only 11 cases, with only 1 case in workers employed at least 20 y ears. On the other hand, mortality from both prostate cancer and multiple myeloma showed statistically significant increases with duration of employment, suggesting the need to explore whether these causes of death may be related to some exposure at the site. The excess of prostate cancer was similar in the early-term subcohort and full NIOSH cohort, evidence that the overall excess is not due to selection bias operating in the early-term subcohort and warrants further follow-up.

NIOSH findings suggest that a future, more comprehensive study might be informative. At the end of follow-up, only $29 \%$ of the early-term subcohort and only $12 \%$ of the late-term subcohort were deceased. Moreover, due to the small number of deaths and the short average duration of employment in the early-term subcohort, longer lag times ( $>1$ years) could not be properly assessed for a number of solid tumor outcomes, and CIs were very wide for many duration of exp osure categories. Procurement of work history data for workers still or first employ ed after 1978 would allow duration-based evaluation of the full NIOSH cohort, facilitate enhanced assessment of the full range of lag times for solid tumors, and reduce the problems of bias discussed above.

While several causes of death show positive trends with duration of employment at the site, exp osure data must be used to assess the actual occupational risk factors behind this surrogate measure. Prostate cancer and multiple my eloma are outcomes of particular interest, although the number of cases of the latter probably precludes in-depth analysis. Records containing specific exp osure information are reported by the Pantex staff to reside on site and at record repositories. While a large portion of these records would need to be computerized before they could be used in an in-depth analysis, this effort is key to elucidation of the findings of this preliminary report. 


\section{REFERENCES}

Acquavella JF, Wiggs LD, Waxweiler RJ, Macdonell DG, Tietjen GL, Wilkinson GS [1985]. Mortality among workers at the Pantex weap ons facility. Health Physics 48:735-46.

ASTDR [1996Site Summary Report on the Pantex Plant in Texas. Agency for Toxic Substances and Disease Registry. Atlanta, GA: Agency for Toxic Substances and Disease Registry.

Baillargeon J, Wilkinson G [1999]. Characteristics of the healthy survivor effect. Am J Ind Epidemiol 35:343-347.

Baillargeon J, Wilkinson G, Rudkin L, Baillargeon G, Ray L [1998]. Characteristics of the healthy worker effect: a comparison of male and female occupational cohorts. J Occ Env Med 40(4):368-373.

Cassinelli R II, Kock KJ, Steenland K, Spaeth S, Laber P [1998]. User documentation PC LTAS. Washington, DC: U.S. Department of Health and Human Services, Centers for Disease Control and Prevention, National Institute for Occup ational Safety and Health.

DOE [1999]. Comprehensive epidemiologic data resource. Washington, DC: U.S. Department of Energy, Office of Epidemiologic Studies, p. 48.

Kolstad H, Olsen J [1999]. Why do short term workers have high mortality? Am J Epidemiol 149(4): 347-351.

NIOSH [2001]. PC-Life Table Analysis Sy stem (Version 1.0 d). Cincinnati, OH: U.S. Department of Health and Human Services, Center for Disease Control and Prevention; National Institute for Occupational Saf ety and Health http://dshefs.niosh.cdc.gov/ltas/LT96MAST.html.

Rothman K [1986]. Modern epidemiology. Boston,MA:Little, Brown, and Comp any, p. 47.

Siebert U, Rothenbacher D, Daniel U, Brenner H [2001]. Demonstration of the healthy worker survivor effect in a cohort of workers in the construction industry. Occ Environ Med 58(12):774-799. 
Table 1. Demographics of full NIOSH cohort and early-term subcohort.

\begin{tabular}{|c|c|c|c|c|c|c|}
\hline & \multicolumn{2}{|c|}{ Full NIOSH cohort ${ }^{*}$} & \multicolumn{2}{|c|}{ Early-term subcohort ${ }^{\dagger}$} & \multicolumn{2}{|c|}{ Late-term subcohort ${ }^{\ddagger}$} \\
\hline White males ${ }^{\ddagger}$ & 3,549 & $(76.0 \%)$ & 2,077 & $(76.3 \%)$ & 1,472 & $(75.6 \%)$ \\
\hline White females & 889 & $(19.0 \%)$ & 569 & $(20.9 \%)$ & 320 & $(16.4 \%)$ \\
\hline Nonwhite males & 152 & $(3.3 \%)$ & 54 & $(2.0 \%)$ & 98 & $(5.0 \%)$ \\
\hline Nonwhite females & 78 & $(1.7 \%)$ & 21 & $(0.8 \%)$ & 57 & $(2.9 \%)$ \\
\hline Total & & 4,668 & & 2,721 & & 1,947 \\
\hline Mean attained age $e^{\S}$ & & 60.0 & & 60.7 & & 59.0 \\
\hline Mean age at hire & & 31.2 & & 30.7 & & 31.8 \\
\hline Mean year of hire & & 1964 & & 1961 & & 1967 \\
\hline $\begin{array}{l}\text { Mean duration of } \\
\text { employment }\end{array}$ & & 7.2 & & 4.4 & & 11.0 \\
\hline
\end{tabular}

\footnotetext{
${ }^{*}$ All workers ever employed at Pantex between the start of operations in 1951 and December 31, 1978.

${ }^{\dagger}$ Limited to those workers who died or terminated employment as of December 31, 1978.

${ }^{\ddagger}$ Note that Hispanics are included in the white category. Workers of unknown race are assumed white and workers of unknown sex are assumed male.

${ }^{\S}$ Age is calculated as age at death for deceased workers and age at end of study (12/31/1995) for all others.

** Duration of employment through later of termination date (early-term subcohort) or 12/31/1978 (late-term subcohort).
}

Table 2. Age distribution* of the full NIOS H cohort and early-term subcohort.

\begin{tabular}{|c|c|c|c|c|}
\hline \multirow[b]{2}{*}{ Age catego ry } & \multicolumn{2}{|c|}{ Full NIOSH cohort $^{\top}$} & \multicolumn{2}{|c|}{ Early-term subcohort ${ }^{\mp}$} \\
\hline & Number & Percent of total & Number & Percent of total \\
\hline $20-29$ & 12 & 0.3 & 11 & 0.4 \\
\hline 30-39 & 90 & 1.9 & 40 & 1.5 \\
\hline $40-49$ & 974 & 20.9 & 511 & 18.8 \\
\hline $50-59$ & 1160 & 24.9 & 711 & 26.1 \\
\hline $60-69$ & 1331 & 28.5 & 765 & 28.1 \\
\hline 70-79 & 868 & 18.6 & 501 & 18.4 \\
\hline 80 and over & 233 & 5.0 & 182 & 6.7 \\
\hline
\end{tabular}

${ }^{*}$ Age is calculated as age at death for deceased workers and age at end of study (12/31/1995) for all others.

${ }^{\dagger}$ All workers ever employed at Pantex between the start of operations in 1951 and December 31, 1978.

${ }^{\ddagger}$ Limited to those workers who died or terminated employment as of December 31, 1978. 
Table 3. Vital status of full NIOSH cohort and early- and late-term subcohorts as of Decmber 31, 1995.

\begin{tabular}{llccc}
\hline & & Alive & Dead & Unknown* \\
\hline $\begin{array}{l}\text { Full NIOSH } \\
\text { cohort } \dagger\end{array}$ & Males & $2,663(71.9 \%)$ & $947(25.6 \%)$ & $91 \quad(2.5 \%)$ \\
& Females & $798(82.5 \%)$ & $85(8.8 \%)$ & $84(8.7 \%)$ \\
& Total & $3,461(74.1 \%)$ & $1,032(22.1 \%)$ & $175(3.8 \%)$ \\
$\begin{array}{l}\text { Early-term } \\
\text { subcohort } \ddagger\end{array}$ & Males & $1,308(61.4 \%)$ & $732(34.3 \%)$ & $91 \quad(4.3 \%)$ \\
& Females & $440(74.6 \%)$ & $68(11.5 \%)$ & $82(13.9 \%)$ \\
& Total & $1,748(64.2 \%)$ & $800(29.4 \%)$ & $173(6.4 \%)$ \\
$\begin{array}{l}\text { Late-term } \\
\text { subcohort§ }\end{array}$ & Males & $1,355(86.3 \%)$ & $215(13.7 \%)$ & 0 \\
& Females & $358(95.0 \%)$ & $17(4.5 \%)$ & $2(0.5 \%)$ \\
& Total & $1,713(88.0 \%)$ & $232(11.9 \%)$ & $2 \quad(0.1 \%)$ \\
\hline
\end{tabular}

${ }^{*}$ Considered alive in all analyses.

${ }^{\dagger}$ All workers ever employed at Pantex between the start of operations in 1951 and December 31, 1978.

${ }^{\ddagger}$ Limited to members of the full NIOSH cohort who died or terminated employment as of December 31, 1978.

${ }^{\S}$ Limited to members of the full NIOSH cohort still employed after December 31, 1978. 
Table 4. S ummary SMR ${ }^{*}$ results-full cohort and early-term subcohort.

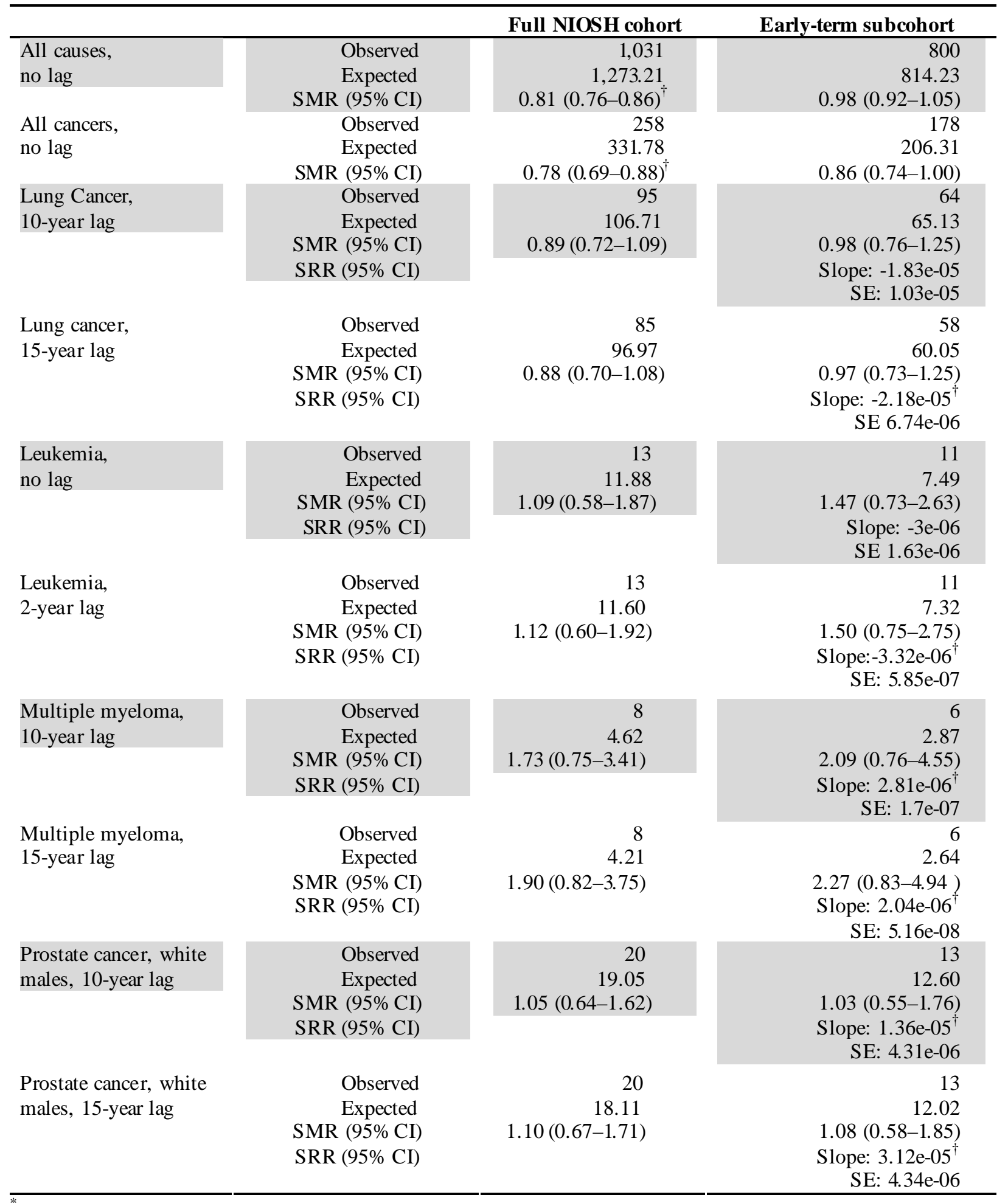

\footnotetext{
*Abbreviations: $\mathrm{CI}=$ confidence interval; SMR = standardized mortality ratio; SRR = standardized rate ratio; $\mathrm{SE}=$ standard error.

${ }^{\dagger}$ 2-sided p-value $<0.05$.

${ }^{\ddagger}$ 2-sided p-value $<0.01$.
} 
Table 5. SMR ${ }^{*}$ and $S R R$ results for early-term subcohort by duration of employment.

\begin{tabular}{|c|c|c|c|c|c|c|}
\hline & \multicolumn{6}{|c|}{ Duration of Employment } \\
\hline & & $0-<5$ years & $5-<10$ years & $10-<20$ years & $>=20$ years & $\begin{array}{l}\text { Totals, slope \& } \\
\text { SE for SRR }\end{array}$ \\
\hline $\begin{array}{l}\text { All causes, no } \\
\text { lag }\end{array}$ & $\begin{array}{l}\text { Observed } \\
\text { Expected } \\
\text { SMR (95\% CI) }\end{array}$ & $\begin{array}{l}505 \\
526.20 \\
0.96(0.88-1.05)\end{array}$ & $\begin{array}{l}94 \\
117.23 \\
0.80(0.65-0.98)\end{array}$ & $\begin{array}{l}142 \\
122.28 \\
1.16(0.98-1.37)\end{array}$ & $\begin{array}{l}59 \\
48.45 \\
1.22(0.93-1.57)\end{array}$ & $\begin{array}{l}800 \\
814.23 \\
0.98(0.92-1.05)\end{array}$ \\
\hline $\begin{array}{l}\text { All cancers, } \\
\text { no lag }\end{array}$ & $\begin{array}{l}\text { Observed } \\
\text { Expected } \\
\text { SMR (95\% CI) }\end{array}$ & $\begin{array}{l}107 \\
134.70 \\
0.79^{\dagger}(0.65-0.96)\end{array}$ & $\begin{array}{l}29 \\
30.18 \\
0.96(0.64-1.39)\end{array}$ & $\begin{array}{l}28 \\
29.49 \\
0.95(0.63-1.38)\end{array}$ & $\begin{array}{l}14 \\
11.94 \\
1.17(0.64-2.00)\end{array}$ & $\begin{array}{l}178 \\
206.31 \\
0.86(0.74-1.00)\end{array}$ \\
\hline $\begin{array}{l}\text { Lung cancer, } \\
10 \text {-year lag }\end{array}$ & $\begin{array}{l}\text { Observed } \\
\text { Expected } \\
\text { SMR (95\% CI) } \\
\text { SRR (95\% CI) }\end{array}$ & $\begin{array}{l}38 \\
44.61 \\
0.85(0.60-1.17) \\
1.00\end{array}$ & $\begin{array}{l}13 \\
10.09 \\
1.29(0.69-2.24) \\
1.69(0.88-3.25)\end{array}$ & $\begin{array}{l}10 \\
8.28 \\
1.21(0.58-2.28) \\
1.62(0.76-3.45)\end{array}$ & $\begin{array}{l}3 \\
2.15 \\
1.40(0.28-4.58) \\
0.34(0.10-1.10)\end{array}$ & $\begin{array}{l}64 \\
65.13 \\
0.98(0.76-1.25) \\
\text { Slope: }-1.83 \mathrm{e}-05 \\
\text { SE: } 1.03 \mathrm{e}-05\end{array}$ \\
\hline $\begin{array}{l}\text { Lung cancer, } \\
15 \text {-year lag }\end{array}$ & $\begin{array}{l}\text { Observed } \\
\text { Expected } \\
\text { SMR (95\% CI) } \\
\text { SRR (95\% CI) }\end{array}$ & $\begin{array}{l}37 \\
42.77 \\
0.87(0.61-1.20) \\
1.00\end{array}$ & $\begin{array}{l}13 \\
9.41 \\
1.38(0.74-2.40) \\
1.61(0.83-3.14)\end{array}$ & $\begin{array}{l}6 \\
6.72 \\
0.89(0.33-2.04) \\
0.93(0.32-2.71)\end{array}$ & $\begin{array}{l}2 \\
1.16 \\
1.73(0.19-7.51) \\
0.22(0.05-0.93)\end{array}$ & $\begin{array}{l}58 \\
60.05 \\
0.97(0.73-1.25)^{\ddagger} \\
\text { Slope: }-2.18 \mathrm{e}-05^{\ddagger} \\
\text { SE 6.74e-06 }\end{array}$ \\
\hline $\begin{array}{l}\text { Leukemia, } \\
\text { no lag }\end{array}$ & $\begin{array}{l}\text { Observed } \\
\text { Expected } \\
\text { SMR (95\% CI) } \\
\text { SRR (95\% CI) }\end{array}$ & $\begin{array}{l}5 \\
4.95 \\
1.01(0.33-2.50) \\
1.00\end{array}$ & $\begin{array}{l}3 \\
1.08 \\
2.78(0.56-9.10) \\
1.65(0.38-7.17)\end{array}$ & $\begin{array}{l}2 \\
1.04 \\
1.93(0.22-8.36) \\
0.86(0.14-5.10)\end{array}$ & $\begin{array}{l}1 \\
0.42 \\
2.39(0.03-19.49) \\
0.48(0.06-4.19)\end{array}$ & $\begin{array}{l}11 \\
7.49 \\
1.47(0.73-2.63) \\
\text { Slope: -3e-06 } \\
\text { SE 1.63e-06 }\end{array}$ \\
\hline $\begin{array}{l}\text { Leukemia, } \\
\text { 2-year lag }\end{array}$ & $\begin{array}{l}\text { Observed } \\
\text { Expected } \\
\text { SMR (95\% CI) } \\
\text { SRR (95\% CI) }\end{array}$ & $\begin{array}{l}6 \\
4.86 \\
1.23(0.45-2.82) \\
1.00\end{array}$ & $\begin{array}{l}2 \\
1.06 \\
1.88(0.21-8.16) \\
1.11(0.22-5.62)\end{array}$ & $\begin{array}{l}2 \\
1.01 \\
1.99(0.22-8.64) \\
0.82(0.14-4.66)\end{array}$ & $\begin{array}{l}1 \\
0.39 \\
2.55(0.03-20.84) \\
0.43(0.05-3.63)\end{array}$ & $\begin{array}{l}11 \\
7.32 \\
1.50(0.75-2.75) \\
\text { Slope:-3.32e-06 } \\
\text { SE: } 5.85 \mathrm{e}-07\end{array}$ \\
\hline $\begin{array}{l}\text { Multiple } \\
\text { myeloma, } \\
10 \text {-year lag }\end{array}$ & $\begin{array}{l}\text { Observed } \\
\text { Expected } \\
\text { SMR (95\% CI) }\end{array}$ & $\begin{array}{l}3 \\
1.93 \\
1.55(0.31-5.08)\end{array}$ & $\begin{array}{l}1 \\
0.43 \\
2.30(0.03-18.80\end{array}$ & $\begin{array}{l}2 \\
0.38 \\
5.22(0.59-22.65)\end{array}$ & 0 & $\begin{array}{l}6 \\
2.87 \\
2.09(0.76-4.55)\end{array}$ \\
\hline & SRR (95\% CI) & 1.00 & $1.16(0.12-11.27)$ & $1.49(0.25-8.98)$ & 0 & $\begin{array}{l}\text { Slope: } 2.81 \mathrm{e}-06^{\ddagger} \\
\text { SE: } 1.7 \mathrm{e}-07\end{array}$ \\
\hline $\begin{array}{l}\text { Multiple } \\
\text { myeloma, } \\
\text { 15-year lag }\end{array}$ & $\begin{array}{l}\text { Observed } \\
\text { Expected } \\
\text { SMR (95\% CI) } \\
\text { SRR (95\% CI) }\end{array}$ & $\begin{array}{l}3 \\
1.84 \\
1.63(0.33-5.33) \\
1.00\end{array}$ & $\begin{array}{l}1 \\
0.41 \\
2.46(0.03-20.03) \\
1.13(0.12-10.96)\end{array}$ & $\begin{array}{l}2 \\
0.32 \\
6.17(0.69-26.80) \\
1.35(0.22-8.17)\end{array}$ & $\begin{array}{l}0 \\
0\end{array}$ & $\begin{array}{l}6 \\
2.64 \\
2.27(0.83-4.94) \\
\text { Slope: } 2.04 \mathrm{e}-06^{\mp} \\
\text { SE: 5.16e-08 }\end{array}$ \\
\hline $\begin{array}{l}\text { Prostate } \\
\text { cancer, } \\
\text { white males, } \\
10 \text {-year lag }\end{array}$ & $\begin{array}{l}\text { Observed } \\
\text { Expected } \\
\text { SMR (95\% CI) } \\
\text { SRR (95\% CI) }\end{array}$ & $\begin{array}{l}5 \\
7.79 \\
0.64(0.21-1.59) \\
1.00\end{array}$ & $\begin{array}{l}2 \\
1.81 \\
1.11(0.12-4.80) \\
1.60(0.31-8.36)\end{array}$ & $\begin{array}{l}4 \\
2.18 \\
1.83(0.49-5.09) \\
2.14(0.54-8.45)\end{array}$ & $\begin{array}{l}2 \\
0.82 \\
2.44(0.27-10.59) \\
7.57(1.03-55.72)\end{array}$ & $\begin{array}{l}13 \\
12.60 \\
1.03(0.55-1.76) \\
\text { Slope: } 1.36 \mathrm{e}-05^{+} \\
\text {SE: 4.31e-06 }\end{array}$ \\
\hline $\begin{array}{l}\text { Prostate } \\
\text { cancer, } \\
\text { white males, } \\
\text { 15-year lag }\end{array}$ & $\begin{array}{l}\text { Observed } \\
\text { Expected } \\
\text { SMR (95\% CI) } \\
\text { SRR (95\% CI) }\end{array}$ & $\begin{array}{l}5 \\
7.75 \\
0.65(0.21-1.60) \\
1.00\end{array}$ & $\begin{array}{l}3 \\
1.81 \\
1.66(0.33-5.43) \\
2.19(0.51-9.38)\end{array}$ & $\begin{array}{l}4 \\
1.95 \\
2.05(0.55-5.70) \\
5.17(1.07-24.91)\end{array}$ & $\begin{array}{l}1 \\
0.51 \\
1.95(0.03-16.00) \\
7.04(0.82-60.37)\end{array}$ & $\begin{array}{l}13 \\
12.02 \\
1.08(0.58-1.85) \\
\text { Slope: 3.12e-05 } \\
\text { SE: 4.34e-06 }\end{array}$ \\
\hline
\end{tabular}

\footnotetext{
*Abbreviations: $\mathrm{CI}=$ confidence interval; $\mathrm{SMR}=$ standardized mortality ratio; $\mathrm{SRR}=$ standardized rate ratio; $\mathrm{SE}=$ standard error.

${ }^{\dagger}$ 2-sided p-value $<0.05$.

${ }^{\ddagger}$ 2-sided p-value $<0.01$.
} 
Table 6. Percent of person-years contributed to employment duration categories by age, early-term cohort, no lag, leukemia $S M^{*}$ and $S R R$ results.

\begin{tabular}{|c|c|c|c|c|}
\hline \multirow[b]{2}{*}{ Age at accrual } & \multicolumn{4}{|c|}{ Final employment duration } \\
\hline & $<5$ years & $5-<10$ years & $10-<20$ years & $>=20$ years \\
\hline$<30$ & $12.6 \%$ & $11.4 \%$ & $6.9 \%$ & $1.4 \%$ \\
\hline $30-39$ & $25 \%$ & $24.3 \%$ & $18.1 \%$ & $9.1 \%$ \\
\hline $40-49$ & $26.7 \%$ & $27.6 \%$ & $23.6 \%$ & $23.6 \%$ \\
\hline $50-59$ & $19.9 \%$ & $20.9 \%$ & $25.1 \%$ & $27.3 \%$ \\
\hline $60-69$ & $11.5 \%$ & $11.6 \%$ & $16.7 \%$ & $22.7 \%$ \\
\hline $70+$ & $4.3 \%$ & $4.3 \%$ & $9.6 \%$ & $15.9 \%$ \\
\hline Total & $100 \%$ & $100 \%$ & $100 \%$ & $100 \%$ \\
\hline SMR & 1.01 & 2.78 & 1.93 & 2.39 \\
\hline SRR & 1 & 1.65 & 0.86 & 0.48 \\
\hline Number of deaths & 5 & 3 & 2 & 1 \\
\hline $\begin{array}{l}\text { Age of cases at } \\
\text { death }\end{array}$ & $\begin{array}{c}50,70,75 \\
75,80\end{array}$ & $30,65,65$ & 40,65 & 75 \\
\hline
\end{tabular}

Table 7. Percent of person-years contributed to employment duration categories by age, early-term cohort, 10-year lag, prostate cancer SMR* and $S R R$ results.

\begin{tabular}{|c|c|c|c|c|}
\hline \multirow[b]{2}{*}{ Age at accrual } & \multicolumn{4}{|c|}{ Final employment duration } \\
\hline & $<5$ years & $5-<10$ years & $10-<20$ years & $>=20$ years \\
\hline$<30$ & $30.4 \%$ & $0.1 \%$ & $0.1 \%$ & $0.1 \%$ \\
\hline $30-39$ & $42.3 \%$ & $13.9 \%$ & $10.4 \%$ & $7.0 \%$ \\
\hline $40-49$ & $18.6 \%$ & $33.0 \%$ & $25.3 \%$ & $19.3 \%$ \\
\hline $50-59$ & $7.2 \%$ & $28.9 \%$ & $27.4 \%$ & $25.7 \%$ \\
\hline $60-69$ & $1.3 \%$ & $16.9 \%$ & $22.3 \%$ & $27.2 \%$ \\
\hline $70+$ & $0.2 \%$ & $7.2 \%$ & $14.5 \%$ & $20.7 \%$ \\
\hline Total & $100 \%$ & $100 \%$ & $100 \%$ & $100 \%$ \\
\hline SMR & 0.64 & 1.11 & 1.83 & 2.44 \\
\hline SRR & 1.00 & 1.60 & 2.14 & 7.57 \\
\hline Number of Deaths & 5 & 2 & 4 & 2 \\
\hline $\begin{array}{l}\text { Age of Cases at } \\
\text { Death }\end{array}$ & $\begin{array}{c}60,65,70 \\
75,75\end{array}$ & 55,75 & $\begin{array}{c}50,65,80, \\
85\end{array}$ & 65,75 \\
\hline
\end{tabular}


Figure-1 SRRs for Leukemia and Aleukemia by Duration of Employment, No Lag

Rothman Trend Test

slope $=-3 \mathrm{E}-06$ standard error $=1.63 \mathrm{E}-06 \mathrm{p}=0.066$

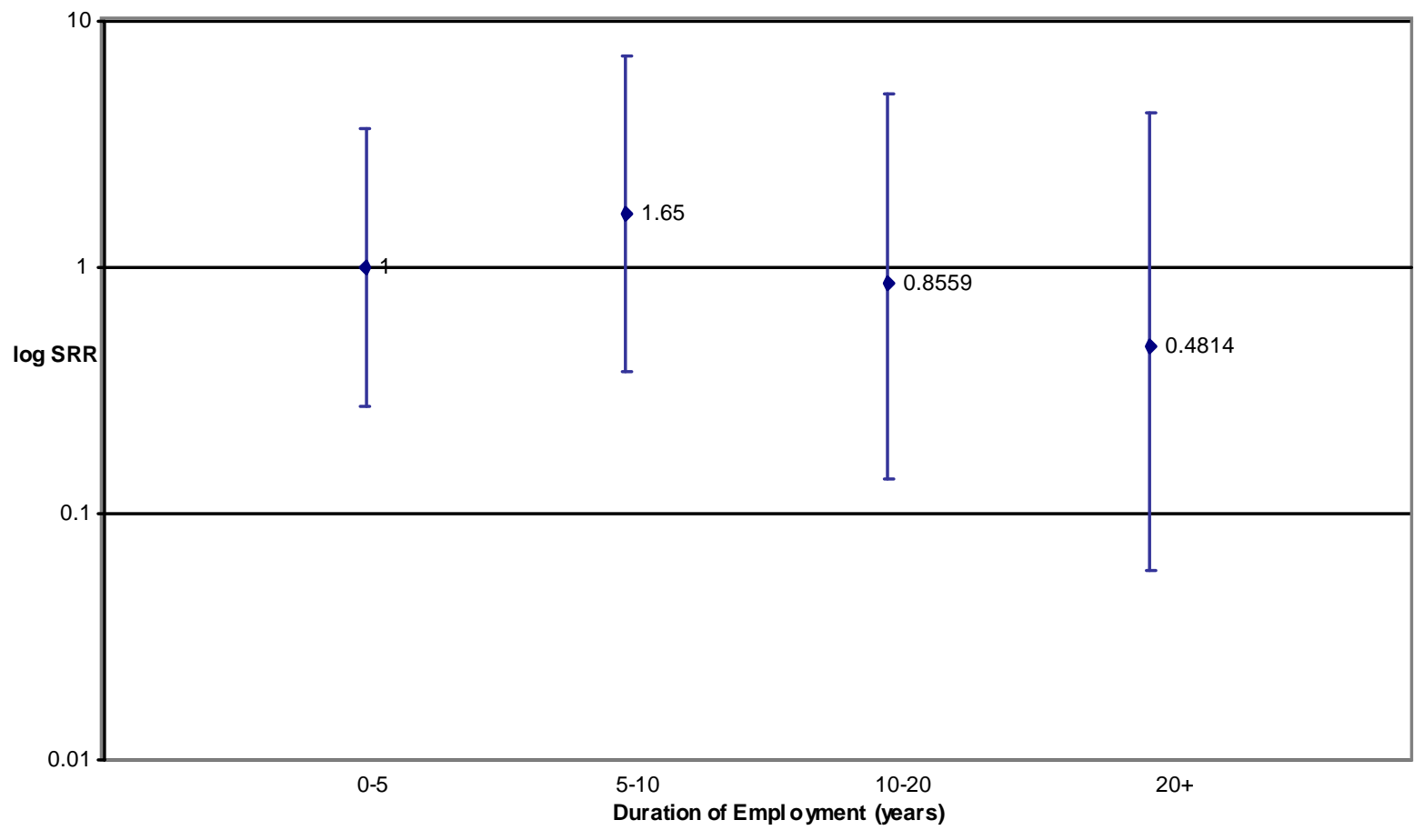


Figure-2 SRRs for Leukemia and Aleukemia by Duration of Employment, 2 Year Lag

Rothman Trend Test

slope=-3.32E-06 standard error=5.85E-07 $p<0.0001$

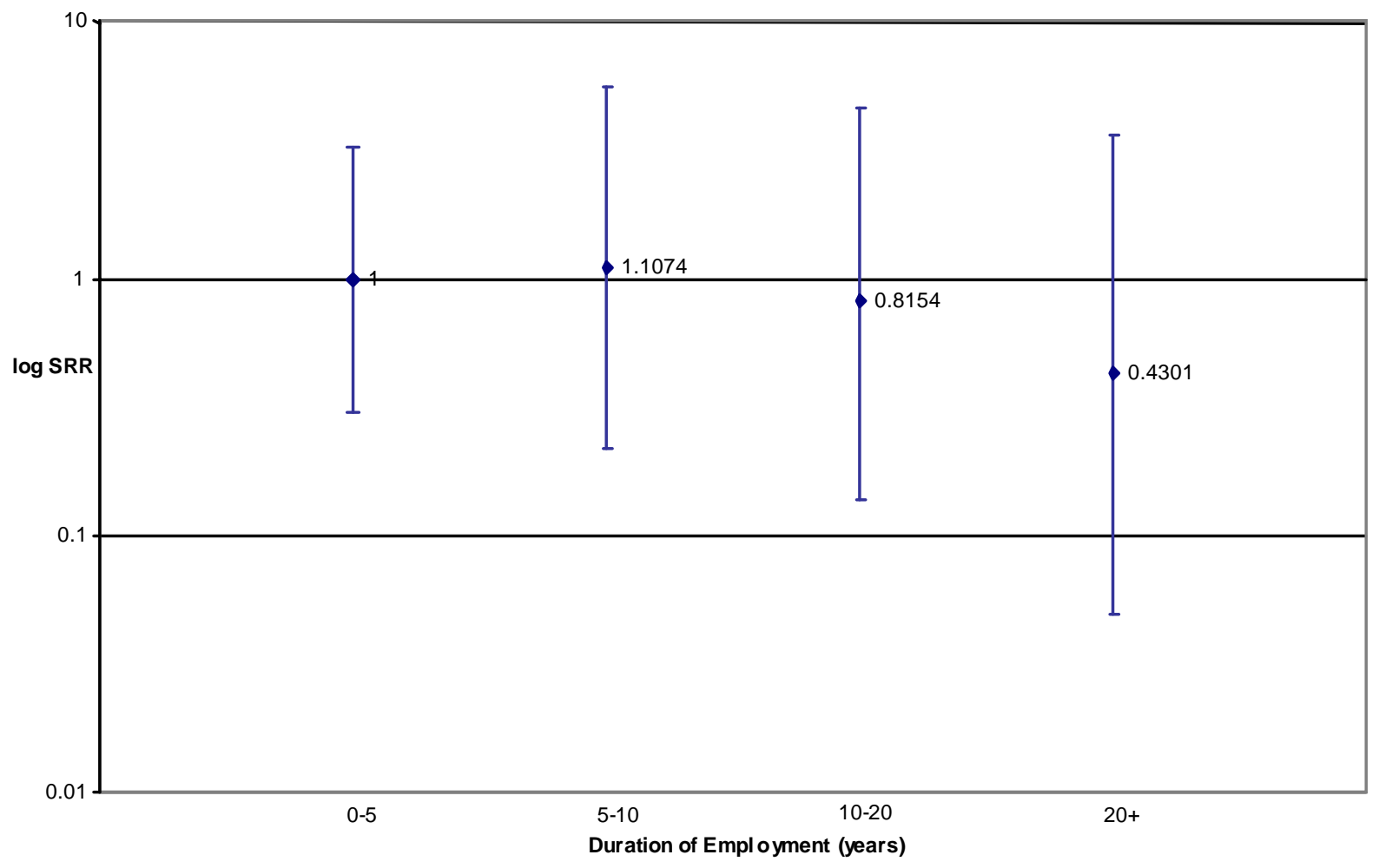


Figure 3- SRRs for Multiple Myeloma by Duration of Employment, 10 Year Lag

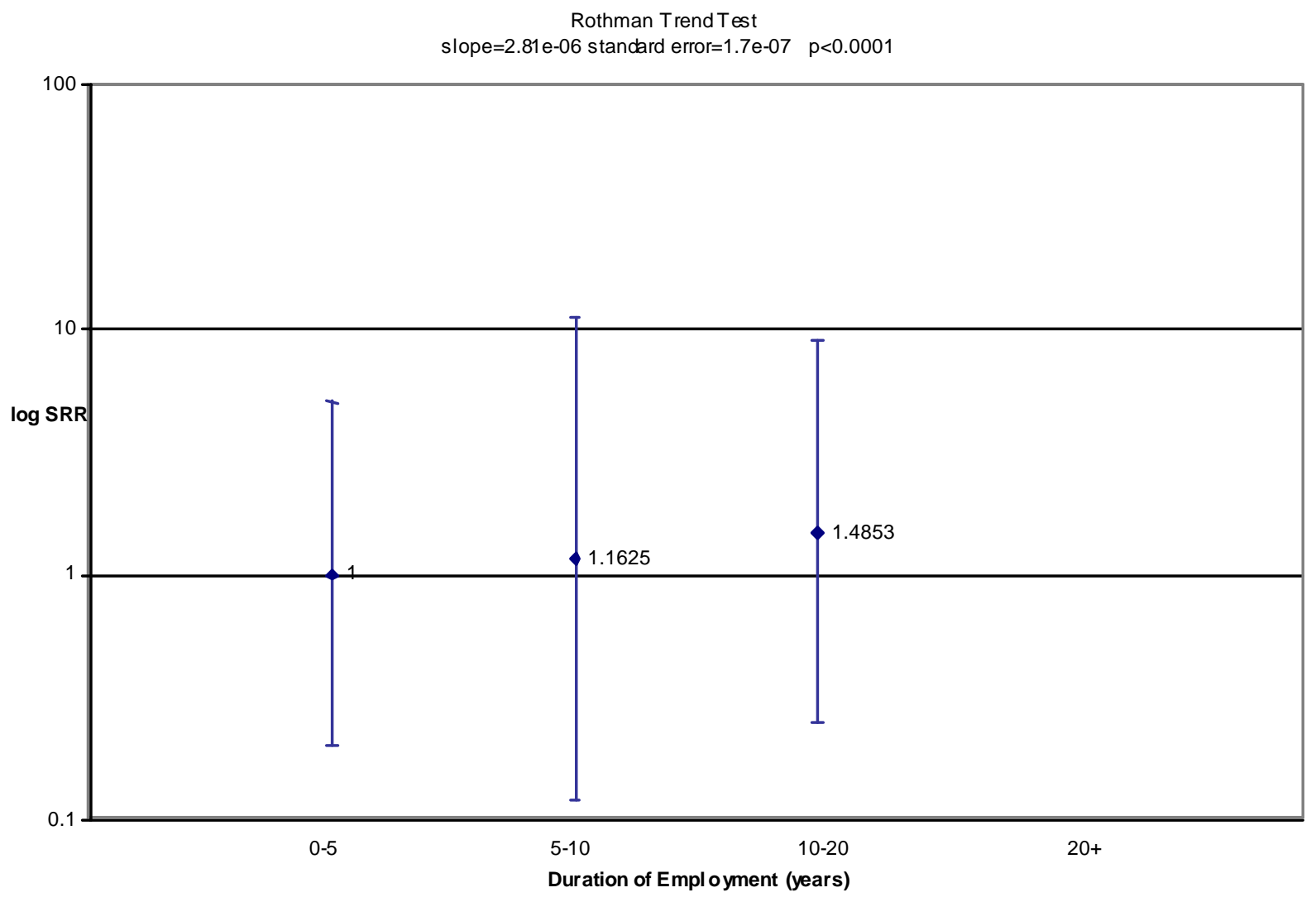


Figure 4- SRRs for Multiple Myeloma by Duration of Employment, 15 Year Lag

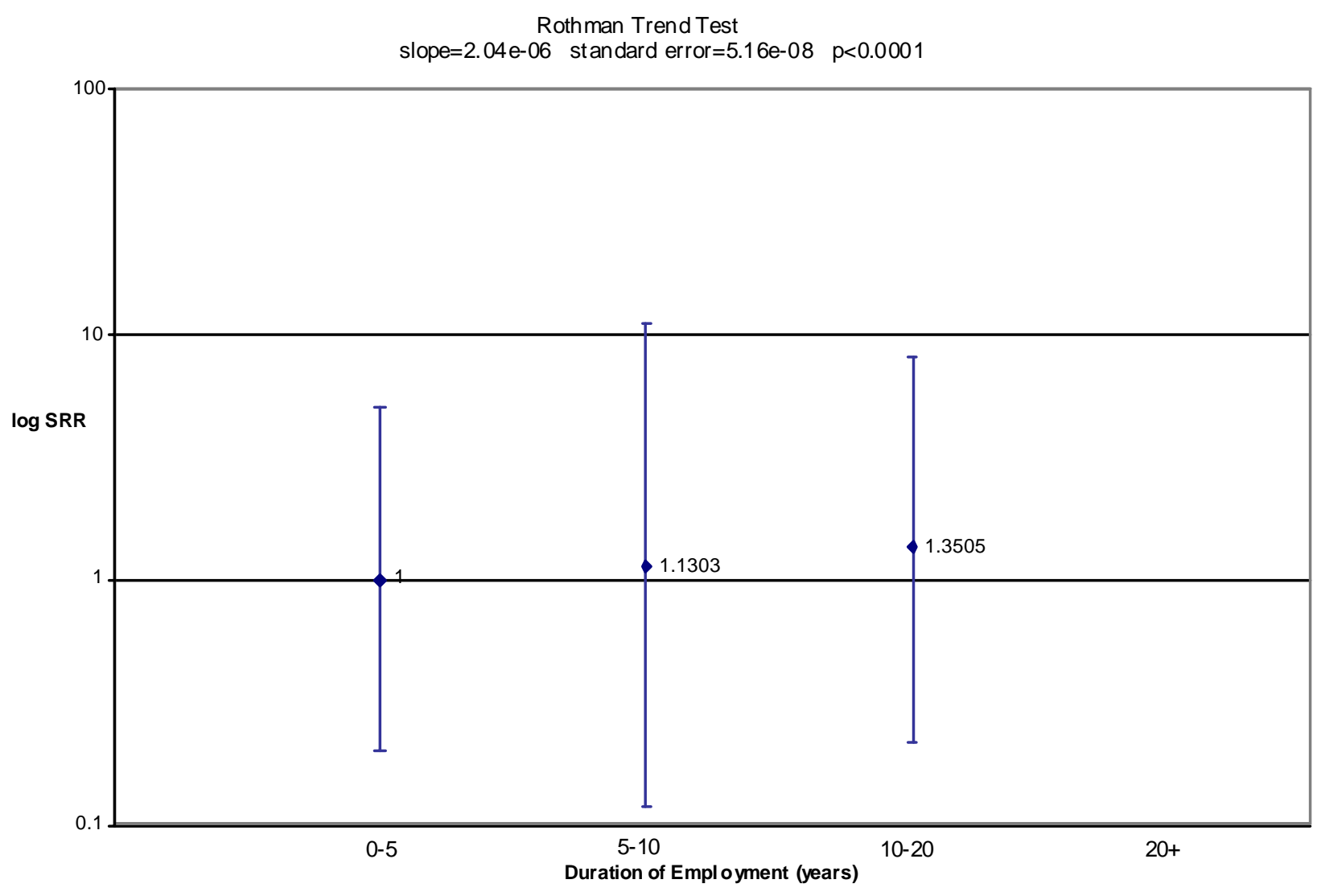


Figure 5- SRRs of Prostate Cancer by Duration of Employment, 10 Year Lag

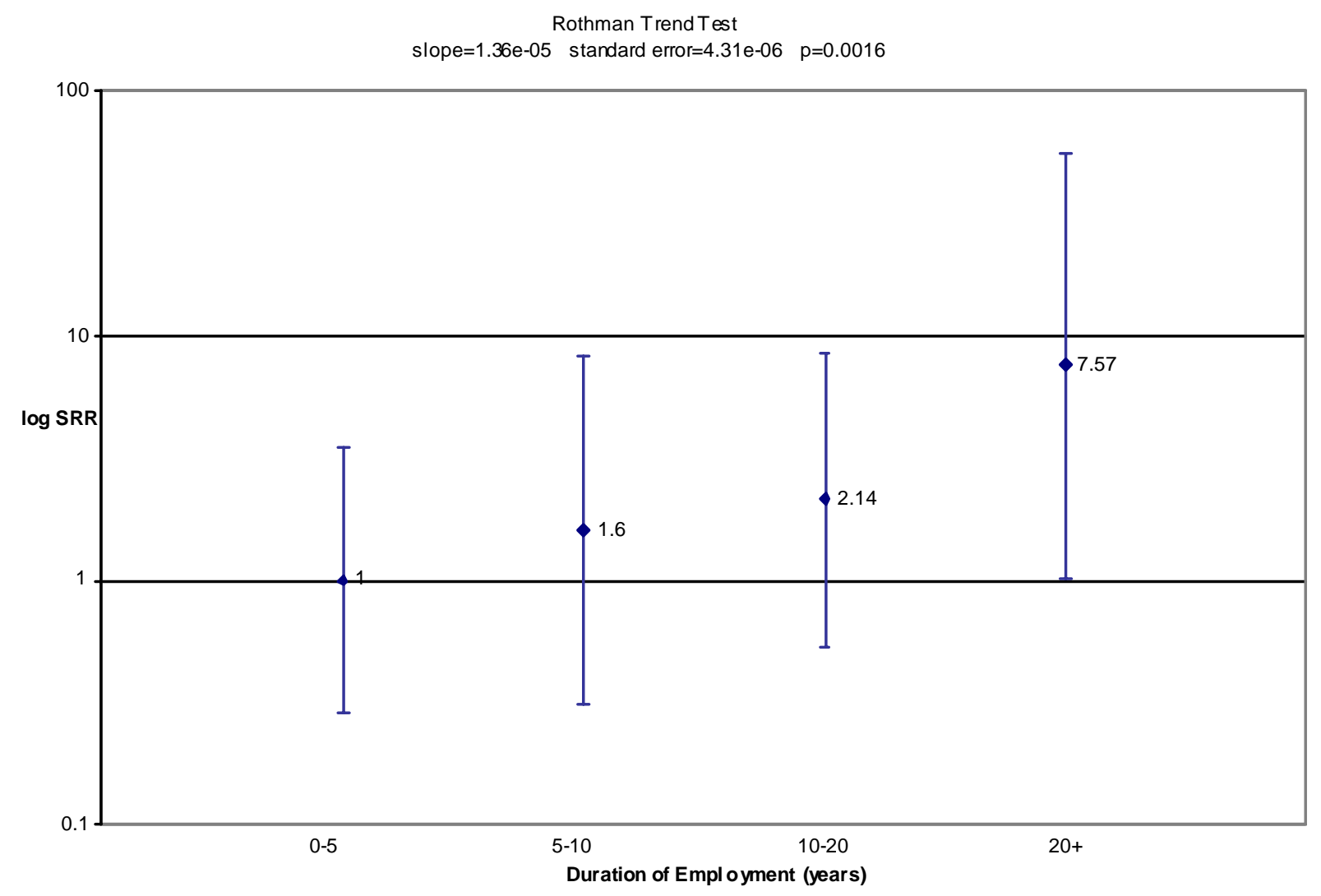


Figure 6- SRRs for Prostate Cancer by Duration of Employment, 15 Year Lag

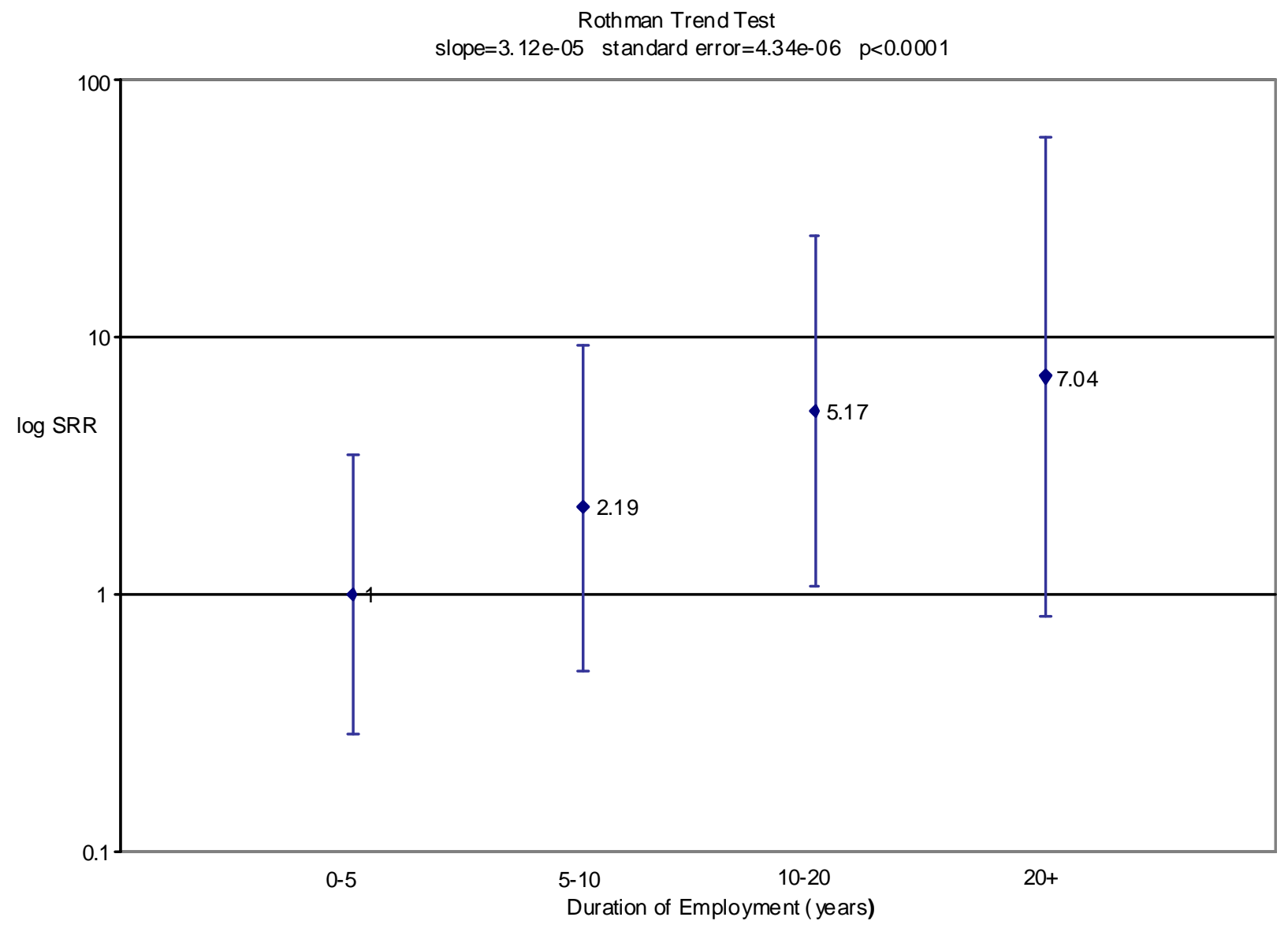


Figure 7- SRRs for Lung Cancer by Duration of Employment, 10 Year Lag

Rothman Trend Test

slope $=-1.83 e-05$ standard error $=1.03 e-05 p=0.0756$

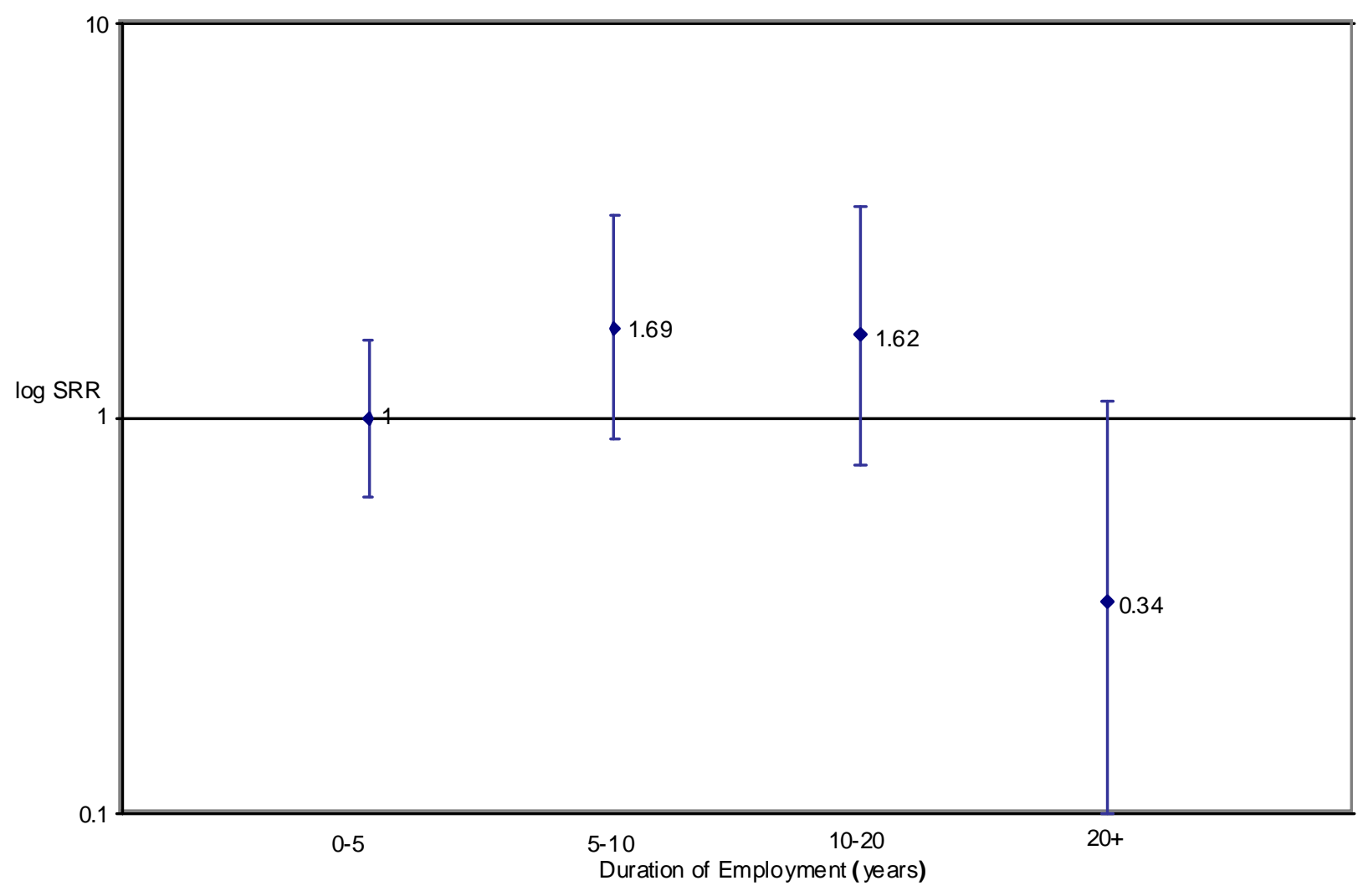


Figure 8- SRRs of Lung Cancer by Duration of Employment, 15 Year Lag

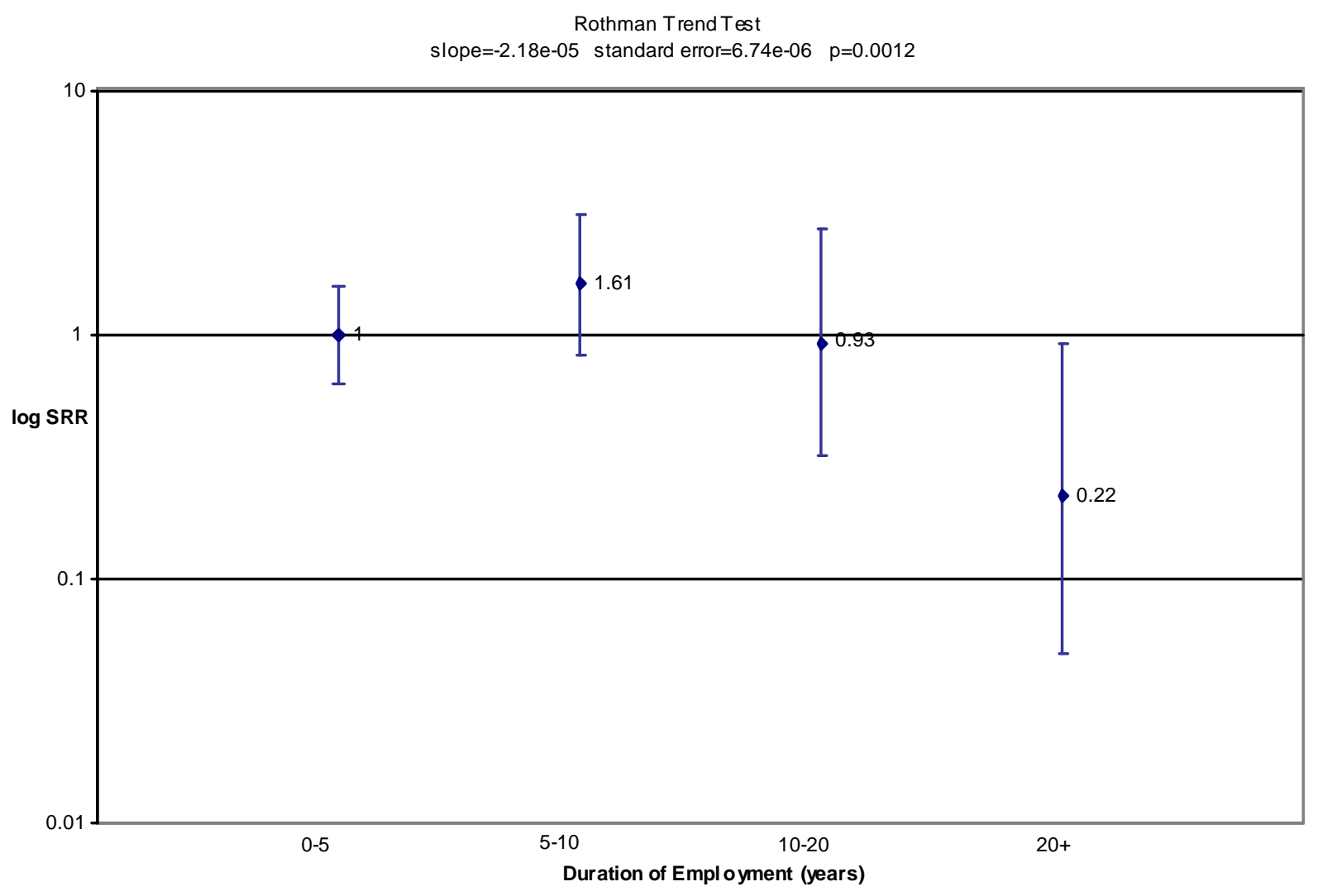




\section{APPENDIX A}

Summary S MR results-full cohort and early-term subcohort, men and women of all races, no lag.

\begin{tabular}{|c|c|c|c|c|c|c|c|c|}
\hline \multirow[b]{2}{*}{ Outcome } & \multicolumn{4}{|c|}{ Full NIOSH Cohort } & \multicolumn{4}{|c|}{ Early-term Subcohort } \\
\hline & Observed & Expected & SMR & $(95 \% \mathrm{CI})$ & Observed & Expected & SMR (9) & 95\% CI) \\
\hline Tuberculosis & 0 & 2.93 & & 0 & 0 & 2.10 & & \\
\hline Respiratory Tuberculosis & 0 & 2.59 & & 0 & 0 & 1.88 & & 0 \\
\hline Other Tuberculosis & 0 & 0.34 & & 0 & 0 & 0.22 & & 0 \\
\hline Malignant Neoplasms (MN) of & 4 & 8.17 & 0.49 & $(0.13-1.25)$ & 3 & 5.01 & 0.60 & $(0.1-1.75)$ \\
\hline Buccal Cavity and Pharynx & & & & & & & & \\
\hline MN of Lip & 1 & 0.12 & 8.03 & $(0.20-44.64)$ & 1 & 0.09 & $11.75(C$ & $(0.30-65.28)$ \\
\hline MN of Tongue & 0 & 1.87 & & 0 & 0 & 1.15 & & 0 \\
\hline MN of Other Buccal & 2 & 2.18 & 0.92 & $(0.11-3.32)$ & 2 & 1.35 & 1.48 & $(0.18-5.34)$ \\
\hline MN of Pharynx & 1 & 4.00 & 0.25 & 1 & 0 & 2.42 & & 0 \\
\hline $\begin{array}{l}\text { MN of Digestive Organs and } \\
\text { Peritoneum }\end{array}$ & 52 & 79.30 & $0.66^{\ddagger}$ & & 36 & 19.99 & 0.72 & $(0.50-1.00)$ \\
\hline MN of Esophagus & 7 & 8.26 & 0.85 & & 4 & 4.86 & 0.82 & $(0.22-2.10)$ \\
\hline MN of Stomach & 8 & 10.77 & 0.74 & & 6 & 6.94 & 0.86 & $(0.32-1.88)$ \\
\hline MN of Intestine except Rectum & 22 & 28.80 & 0.76 & & 17 & 18.29 & 0.93 & $(0.54-1.49)$ \\
\hline MN of Rectum & 2 & 6.43 & 0.31 & & 2 & 4.21 & 0.47 & $(0.06-1.71)$ \\
\hline $\begin{array}{l}\text { MN of Biliary Passages, Liver } \\
\text { and Gallbladder }\end{array}$ & 3 & 5.49 & 0.55 & $(0.11-1.60)$ & 2 & 3.39 & 0.59 & $(0.07-2.13)$ \\
\hline MN of Liver, not specified & 0 & 2.13 & & 0 & 0 & 1.36 & & 0 \\
\hline MN of Pancreas & 10 & 16.15 & 0.62 & & 5 & 10.12 & 0.49 & $(0.16-1.15)$ \\
\hline $\begin{array}{l}\text { MN of Peritoneum and Other } \\
\text { and Unspeci fied Digestive } \\
\text { Organs }\end{array}$ & 0 & 1.26 & & & 0 & 0.81 & & 0 \\
\hline MN of Respiratory System & 97 & 120.37 & 0.81 & & 65 & 72.83 & 0.89 & $(0.69-1.14)$ \\
\hline MN of Larynx & 1 & 4.03 & 0.25 & & 1 & 2.46 & 0.41 & $(0.01-2.25)$ \\
\hline $\begin{array}{l}\text { MN of Trachea, Bronchus } \\
\text { and Lung }\end{array}$ & 95 & 115.12 & 0.83 & $(0.67-1.01)$ & 64 & 69.61 & 0.92 & $(0.71-1.17)$ \\
\hline $\begin{array}{l}\text { MN of Other Parts of } \\
\text { Respiratory System }\end{array}$ & 1 & 1.22 & 0.82 & $(0.02-4.56)$ & 0 & 0.76 & & 0 \\
\hline MN of Breast & 5 & 8.98 & 0.56 & $(0.18-1.30)$ & 5 & 6.17 & 0.81 & $(0.26-1.89)$ \\
\hline MN of Female Genital Organs & 1 & 4.84 & 0.21 & $(0.001-1.15)$ & 1 & 3.42 & 0.29 & $(0.01-1.63)$ \\
\hline MN of Cervix and Uteri & 0 & 1.32 & & 0 & 0 & 0.92 & & 0 \\
\hline $\begin{array}{l}\text { MN of Other and Unspeci fied } \\
\text { Parts Of Uterus }\end{array}$ & 0 & 0.91 & & 0 & 0 & 0.66 & & 0 \\
\hline $\begin{array}{l}\text { MN of Ovary, Fallopian } \\
\text { Tube, and Broad Ligament }\end{array}$ & 1 & 2.48 & 0.40 & $(0.01-2.24)$ & 1 & 1.75 & 0.57 & $(0.01-3.17)$ \\
\hline $\begin{array}{l}\text { MN of Other Female Genital } \\
\text { Organs }\end{array}$ & 0 & 0.13 & & 0 & 0 & 0.09 & & 0 \\
\hline MN of Male Genital Organs & 21 & 21.53 & 0.98 & $(0.60-1.49)$ & 13 & 14.01 & 0.93 & $(0.49-1.59)$ \\
\hline MN of Prostate & 21 & 20.41 & 1.03 & $(0.64-1.57)$ & 13 & 13.31 & 0.98 & $(0.52-5.24)$ \\
\hline $\begin{array}{l}\text { MN of Other Male Genital } \\
\text { Organs }\end{array}$ & 0 & 1.12 & & 0 & 0 & 0.70 & & 0 \\
\hline MN of Urinary Organs & 14 & 15.33 & 0.91 & $(0.50-1.53)$ & 8 & 9.73 & 0.82 & $(0.35-1.62)$ \\
\hline MN of Kidney & 8 & 8.13 & 0.98 & $(0.42-1.94)$ & 4 & 4.98 & 0.80 & $(0.22-2.05)$ \\
\hline MN of Bladder and Other & 6 & 7.20 & 0.83 & $(0.30-1.82)$ & 4 & 4.75 & 0.84 & $(0.23-2.16)$ \\
\hline
\end{tabular}

(Continued) 


\begin{tabular}{|c|c|c|c|c|c|c|c|}
\hline \multirow[b]{2}{*}{ Outcome } & \multicolumn{4}{|c|}{ Full NIOSH Cohort } & \multicolumn{3}{|c|}{ Early-term Subcohort } \\
\hline & Observed & Expected & $\overline{\text { SMR }}$ & $(95 \% \mathrm{CI})$ & Observed & Expected & SMR (95\% CI) \\
\hline MN Other Unspeci fied Sites & 35 & 42.44 & 0.82 & & 25 & 25.95 & $0.96(0.62-1.42)$ \\
\hline MN of Skin & 5 & 7.08 & 0.71 & $(0.23-1.65)$ & 2 & 4.26 & $0.47(0.06-1.69)$ \\
\hline MN of Eye & 0 & 0.21 & & 0 & 0 & 0.14 & 0 \\
\hline $\begin{array}{l}\text { MN of Brain and Other Parts of } \\
\text { Nervous System }\end{array}$ & 5 & 9.78 & 0.51 & $(0.17-1.19)$ & 4 & 5.97 & $0.67(0.18-1.71)$ \\
\hline MN of Thyroid & 0 & 0.60 & & 0 & 0 & 0.38 & 0 \\
\hline MN of Bone & 0 & 0.90 & & 0 & 0 & 0.59 & 0 \\
\hline $\begin{array}{l}\text { MN of Connective Tissue and } \\
\text { Soft Tissue }\end{array}$ & 0 & 1.82 & & 0 & 0 & 1.09 & 0 \\
\hline $\begin{array}{l}\text { MN of Other and Unspecified } \\
\text { Sites (Minor) }\end{array}$ & 25 & 22.06 & 1.13 & $(0.73-1.67)$ & 19 & 13.52 & $1.41 \quad(0.85-2.20$ \\
\hline $\begin{array}{l}\text { Neoplasms of Lymphatic and } \\
\text { Hematopoietic Tissue }\end{array}$ & 29 & 30.82 & 0.94 & $(0.63-1.35)$ & 22 & 19.22 & $1.14(0.72-1.73)$ \\
\hline $\begin{array}{l}\text { Lymphosarcoma and } \\
\text { Reticulosarcoma }\end{array}$ & 3 & 3.56 & 0.84 & $(0.17-2.46)$ & 3 & 2.40 & $1.25 \quad(0.26-3.66)$ \\
\hline Hodgkin’s Disease & 1 & 2.36 & 0.42 & $(0.01-2.35)$ & 1 & 1.53 & $0.66(0.02-3.64)$ \\
\hline Leukemia and Aleukemia & 13 & 11.88 & 1.09 & $(0.58-1.87)$ & 11 & 7.49 & $1.47(0.73-2.63)$ \\
\hline $\begin{array}{l}\text { Other Neoplasms of Lymphatic } \\
\text { Hematopoietic Tissue }\end{array}$ & 12 & 13.02 & 0.92 & $(0.48-1.61)$ & 7 & 7.81 & $0.90 \quad(0.36-1.85)$ \\
\hline $\begin{array}{l}\text { Benign and Unspecifi ed } \\
\text { Neoplasms }\end{array}$ & 3 & 4.05 & 0.74 & $(0.15-2.17)$ & 2 & 2.60 & $0.77 \quad(0.09-2.78)$ \\
\hline $\begin{array}{l}\text { Benign Neoplasms of the Eye, } \\
\text { Brain, and other parts of the } \\
\text { Nervous System }\end{array}$ & 0 & 0.54 & & 0 & 0 & 0.36 & 0 \\
\hline $\begin{array}{l}\text { Neoplasms of the Eye, } \\
\text { Brain, and other parts of the } \\
\text { Nervous System, Unspecified }\end{array}$ & 3 & 1.81 & 1.66 & $(0.34-4.84)$ & 2 & 1.14 & $1.76 \quad(0.21-6.34)$ \\
\hline $\begin{array}{l}\text { Other Benign and Unspecified } \\
\text { Nature Neoplasms }\end{array}$ & 0 & 1.69 & & 0 & 0 & 1.10 & 0 \\
\hline Diabetes Mellitus & 14 & 22.45 & 0.62 & $(0.34-1.05)$ & 11 & 14.07 & $0.78(0.39-1.40)$ \\
\hline $\begin{array}{l}\text { Diseases of the Blood and Blood } \\
\text { Forming Organs }\end{array}$ & 2 & 3.89 & 0.51 & $(0.06-1.86)$ & 2 & 2.48 & $0.81 \quad(0.10-2.91)$ \\
\hline Pernicious Anemias & 1 & 0.06 & 16.94 & $(0.43-94.09)$ & 1 & 0.05 & $21.70(0.55-120.57)$ \\
\hline $\begin{array}{l}\text { Anemias of Other and } \\
\text { Unspecified Type }\end{array}$ & 0 & 1.35 & & 0 & 0 & 0.89 & 0 \\
\hline $\begin{array}{l}\text { Coagulation Defects, Purpura, } \\
\text { and other Hemorrhagic } \\
\text { Conditions }\end{array}$ & 0 & 0.98 & & 0 & 0 & 0.60 & 0 \\
\hline $\begin{array}{l}\text { All other Diseases of Blood } \\
\text { Forming Organs }\end{array}$ & 1 & 1.50 & 0.67 & $(0.02-3.71)$ & 1 & 0.95 & $1.05 \quad(0.03-5.83)$ \\
\hline $\begin{array}{l}\text { Mental, Psychoneurotic, and } \\
\text { Personality Disorders }\end{array}$ & 7 & 11.00 & 0.64 & $(0.25-1.31)$ & 6 & 6.65 & $0.90 \quad(0.33-1.96)$ \\
\hline Alcoholism & 3 & 5.70 & 0.53 & $(0.11-1.53)$ & 3 & 3.25 & $0.92(0.19-2.70)$ \\
\hline Other Mental Disorders & 4 & 5.30 & 0.76 & $(0.21-1.93)$ & 3 & 3.41 & $0.88(0.18-2.58)$ \\
\hline $\begin{array}{l}\text { Diseases of the Nervous System } \\
\text { and Sense Organs }\end{array}$ & 19 & 16.75 & 1.13 & $(0.68-1.77)$ & 14 & 10.63 & $1.32(0.72-2.21)$ \\
\hline Multiple Sclerosis & 2 & 1.54 & 1.30 & $(0.16-4.69)$ & 2 & 0.96 & $2.09(0.25-7.55)$ \\
\hline $\begin{array}{l}\text { Other Diseases of the Nervous } \\
\text { System and Sense Organs }\end{array}$ & 17 & 15.21 & 1.12 & $(0.65-1.79)$ & 12 & 9.67 & $1.24 \quad(0.64-2.17)$ \\
\hline Diseases of the Heart & 348 & 456.90 & $0.76^{\ddagger}$ & $(0.68-0.85)$ & 266 & 299.39 & $0.89(0.78-1.00)$ \\
\hline Rheumatic Heart Disease & 11 & 7.51 & 1.46 & $(0.73-2.62)$ & 11 & 5.22 & $2.11^{\dagger}(1.05-3.77)$ \\
\hline Ischemic Heart Disease & 252 & 359.92 & $0.70^{7}$ & $(0.62-0.79)$ & 194 & 238.48 & $0.81^{\ddagger}(0.70-0.94)$ \\
\hline $\begin{array}{l}\text { Chronic Disease of } \\
\text { Endocardium }\end{array}$ & 6 & 4.31 & 1.39 & $(0.51-3.03)$ & 3 & 2.77 & $1.08(0.22-3.65)$ \\
\hline Other Myocardial Degeneration & 2 & 2.50 & 0.80 & $(0.10-2.89)$ & 2 & 1.98 & $\begin{array}{r}1.01 \text { (0.12-3.62) } \\
\text { (Continued) }\end{array}$ \\
\hline
\end{tabular}




\begin{tabular}{|c|c|c|c|c|c|c|}
\hline \multirow[b]{2}{*}{ Outcome } & \multicolumn{3}{|c|}{ Full NIOSH Cohort } & \multicolumn{3}{|c|}{ Early-term Subcohort } \\
\hline & Observed & Expected & SMR (95\%CI) & Observed & Expected & SMR $(95 \%$ CI) \\
\hline $\begin{array}{l}\text { Hypertension with Heart } \\
\text { Disease }\end{array}$ & 3 & 10.90 & $0.28^{\dagger}(0.06-0.81)$ & 3 & 7.09 & $0.42 \quad(0.09-1.24)$ \\
\hline Other Diseases of the Heart & 74 & 71.77 & $1.03(0.81-1.29)$ & 53 & 43.85 & $1.21 \quad(0.91-1.58)$ \\
\hline $\begin{array}{l}\text { Other Diseases of the Circulatory } \\
\text { System }\end{array}$ & 82 & 97.24 & $0.84(0.67-1.05)$ & 72 & 66.10 & $1.09 \quad(0.85-1.37)$ \\
\hline $\begin{array}{l}\text { Hypertension without Heart } \\
\text { Disease }\end{array}$ & 0 & 3.74 & $0^{\dagger}$ & 0 & 2.44 & 0 \\
\hline Cerebrovascular Disease & 44 & 62.32 & $0.71^{\dagger}(0.51-0.95)$ & 39 & 43.06 & $0.91(0.64-1.24)$ \\
\hline $\begin{array}{l}\text { Diseases of the Arteries, Veins, } \\
\text { and Pulmonary Circulation }\end{array}$ & 38 & 31.18 & $1.22(0.86-1.67)$ & 33 & 20.61 & $1.60^{\dagger}(1.10-2.25)$ \\
\hline Diseases of the Respiratory System & 81 & 87.60 & $0.92(0.73-1.15)$ & 68 & 57.49 & $1.18 \quad(0.92-1.50)$ \\
\hline $\begin{array}{l}\text { Acute Respiratory Infections } \\
\text { except Influen za and } \\
\text { Pneumonia }\end{array}$ & 1 & 0.41 & $2.42(0.06-13.43)$ & 1 & 0.28 & 3.58 (0.09-19.90) \\
\hline Influenza & 0 & 0.80 & 0 & 0 & 0.59 & 0 \\
\hline Pneumonia (except newborn) & 24 & 26.33 & $0.91(0.58-1.36)$ & 21 & 17.86 & $1.18(0.73-1.80)$ \\
\hline Chronic and Unspecified & 1 & 2.60 & $0.38(0.01-2.14)$ & 0 & 7.81 & 0 \\
\hline Bronchitis & & & & & & \\
\hline Emphysema & 13 & 13.16 & $0.99(0.53-1.69)$ & 12 & 8.99 & $1.33 \quad(0.69-2.33)$ \\
\hline Asthma & 4 & 2.20 & $1.82(0.50-4.66)$ & 3 & 1.42 & $2.12(0.44-6.18)$ \\
\hline $\begin{array}{l}\text { Pneumoconioses and other } \\
\text { Respiratory Diseases }\end{array}$ & 38 & 42.10 & $0.90 \quad(0.64-1.24)$ & 31 & 26.53 & $1.17 \quad(0.79-1.66)$ \\
\hline Diseases of the Digestive System & 36 & 60.83 & $0.59^{\ddagger}(0.41-0.82)$ & 28 & 38.02 & $0.74 \quad(0.49-1.06)$ \\
\hline $\begin{array}{l}\text { Diseases of the Stomach and } \\
\text { Duodenum }\end{array}$ & 7 & 5.82 & $1.20(0.48-2.48)$ & 6 & 4.00 & $1.50 \quad(0.55-3.27)$ \\
\hline $\begin{array}{l}\text { Hernia and Intestinal } \\
\text { Obstruction }\end{array}$ & 1 & 2.32 & $0.43 \quad(0.01-2.39)$ & 1 & 1.63 & $0.61 \quad(0.02-3.40)$ \\
\hline Cirrhosis of the Liver & 17 & 33.64 & $0.51^{\ddagger}(0.29-0.81)$ & 13 & 20.26 & $0.64 \quad(0.34-1.10)$ \\
\hline $\begin{array}{l}\text { Other Diseases of the } \\
\text { Digestive System }\end{array}$ & 11 & 19.04 & $0.58 \quad(0.29-1.03)$ & 8 & 12.13 & $0.66 \quad(0.28-1.30)$ \\
\hline $\begin{array}{l}\text { Diseases of the Genito-Urinary } \\
\text { System }\end{array}$ & 8 & 15.26 & $0.52 \quad(0.23-1.03)$ & 6 & 10.25 & $0.59 \quad(0.21-1.27)$ \\
\hline $\begin{array}{l}\text { Acute Glomerulonephritis, } \\
\text { Nephrotic Syndrome, and } \\
\text { Acute Renal Failure }\end{array}$ & 0 & 1.48 & 0 & 0 & 0.97 & 0 \\
\hline $\begin{array}{l}\text { Chronic and Unspecified } \\
\text { Nephritis, Renal Failure, } \\
\text { and other Renal Sclerosis }\end{array}$ & 4 & 7.48 & $0.53 \quad(0.15-1.37)$ & 4 & 4.87 & $0.82 \quad(0.22-2.10)$ \\
\hline Infection of Kidney & 1 & 1.15 & $0.87 \quad(0.02-4.83)$ & 1 & 0.88 & $1.14 \quad(0.03-6.31)$ \\
\hline Calculi of Urinary System & 0 & 0.29 & 0 & 0 & 0.21 & 0 \\
\hline Hyperplasia of Prostate & 1 & 0.42 & $2.36 \quad(0.06-13.13)$ & 0 & 0.35 & 0 \\
\hline $\begin{array}{l}\text { Other Diseases of Male } \\
\text { Genital Organs }\end{array}$ & 1 & 0.24 & $4.10 \quad(0.10-22.78)$ & 1 & 0.17 & $5.80 \quad(0.15-32.25)$ \\
\hline Diseases of the Breast & 0 & 0.01 & 0 & 0 & 0.004 & 0 \\
\hline $\begin{array}{l}\text { Diseases of the Female } \\
\text { Genital Organs }\end{array}$ & 0 & 0.08 & 0 & 0 & 0.06 & 0 \\
\hline $\begin{array}{l}\text { Other Genito-Urinary System } \\
\text { Diseases }\end{array}$ & 1 & 4.11 & $0.24 \quad(0.01-1.35)$ & 0 & 2.73 & 0 \\
\hline Diseases of the Skin and & 0 & 1.04 & 0 & 0 & 0.69 & 0 \\
\hline $\begin{array}{l}\text { Subcutaneous Tissue } \\
\text { Infections of the Skin and }\end{array}$ & & & & & & \\
\hline $\begin{array}{l}\text { Infections of the Skin and } \\
\text { Subcutaneous Tissue }\end{array}$ & 0 & 0.34 & 0 & 0 & 0.21 & 0 \\
\hline
\end{tabular}




\begin{tabular}{|c|c|c|c|c|c|c|c|}
\hline \multirow[b]{2}{*}{ Outcome } & \multicolumn{4}{|c|}{ Full NIOSH Cohort } & \multicolumn{3}{|c|}{ Early-term Subcohort } \\
\hline & Observed & Expected & SMR & $(95 \% \mathrm{CI})$ & Observed & Expected & SMR (95\% CI) \\
\hline $\begin{array}{l}\text { Other Infections of the Skin } \\
\text { and Subcutaneous Tissue }\end{array}$ & 0 & 0.71 & & 0 & 0 & 0.48 & 0 \\
\hline $\begin{array}{l}\text { Other Diseases of the } \\
\text { Musculoskeletal System }\end{array}$ & 0 & 1.62 & & 0 & 0 & 1.00 & 0 \\
\hline $\begin{array}{l}\text { Symptoms and Ill-Defined } \\
\text { Conditions }\end{array}$ & 17 & 13.72 & 1.24 & $(0.72-1.98)$ & 15 & 8.51 & $1.76(0.99-2.91)$ \\
\hline Accidents & 58 & 74.05 & 0.78 & $(0.59-1.01)$ & 47 & 45.59 & $1.03(0.76-1.37)$ \\
\hline Transportation Accidents & 36 & 41.01 & 0.88 & $(0.61-1.22)$ & 29 & 25.12 & $1.15(0.77-1.66)$ \\
\hline Accidental Poisoning & 1 & 4.22 & 0.24 & $(0.01-1.32)$ & 1 & 2.43 & $0.41(0.01-2.28)$ \\
\hline Accidental Falls & 5 & 7.53 & 0.66 & $(0.21-1.55)$ & 4 & 4.94 & $0.81 \quad(0.22-2.07)$ \\
\hline Other Accidents & 12 & 19.54 & 0.61 & $(0.32-1.07)$ & 9 & 11.99 & $0.75 \quad(0.34-1.42)$ \\
\hline $\begin{array}{l}\text { Medical Complications and } \\
\text { Misadventure }\end{array}$ & 4 & 1.75 & 2.29 & $(0.62-5.86)$ & 4 & 1.10 & $3.63 \quad(0.99-9.28)$ \\
\hline Violence & 29 & 42.43 & $0.68^{\dagger}$ & $(0.46-0.98)$ & 24 & 24.88 & $0.96 \quad(0.62-1.44)$ \\
\hline Suicide & 23 & 29.87 & 0.77 & $(0.49-1.16)$ & 19 & 18.11 & $1.05(0.63-1.64)$ \\
\hline Homocide & 6 & 12.57 & 0.48 & $(0.17-1.04)$ & 5 & 6.77 & $0.74 \quad(0.24-1.73)$ \\
\hline Other Causes & 68 & 28.41 & $2.39^{\ddagger}$ & $(1.86-3.03)$ & 60 & 16.64 & $3.61^{\ddagger}(2.75-4.64)$ \\
\hline All Cancers & 258 & 331.78 & $0.78^{\ddagger}$ & $(0.69-0.88)$ & 178 & 206.31 & $0.86 \quad(0.74-1.00)$ \\
\hline All Deaths & 1031 & 1273.2 & $0.81^{\ddagger}$ & $(0.76-0.86)$ & 800 & 814.23 & $0.98 \quad(0.92-1.05)$ \\
\hline
\end{tabular}

*Abbreviations: $\mathrm{CI}=$ confidence interval; SMR = standardized mortality ratio.

${ }^{\dagger}$ 2-sided p-value $<0.05$.

${ }^{\ddagger}$ 2-sided p-value $<0.01$. 
DEPARTMENT OF HEALTH AND HUMAN SERVICES

Centers for Disease Control and Prevention

National Institute for Occupational Safety and Health

4676 Columbia Parkway

Cincinnati, OH 45226-1998

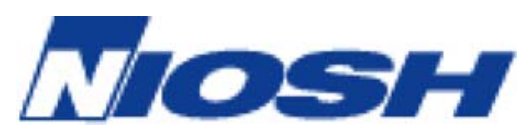

Delivering on the Nation's promise:

Safety and health at work for all people

through research and prevention

To receive NIOSH documents or more information about occupational safety and health topics, contact NIOSH at

1-800-35-NIOSH (1-800-356-4674)

Fax: 513-533-8573

E-mail: pubstaft@cdc.gov

or visit the NIOSH Web site at

www.cdc.gov/niosh

DHHS (NIOSH) Publication No. 2005-124 